\title{
Development Analysis of Ability Memorizing the Qur'an on Early Childhood in PAUD Bait Qurany Saleh Rahmany, Banda Aceh, Indonesia
}

\author{
Dahliani $^{1}$, Anita Yus ${ }^{2}$, Masganti Sitorus ${ }^{3}$ \\ ${ }_{1,2,3}$ Postgraduate Basic Education Study Program, State University of Medan, Indonesia \\ dahlia.ni99@yahoo.co.id
}

\begin{abstract}
This study aims to: (1) Analyze the implementation of learning to memorize the Qur'an in early childhood, (2) Analyze the ability to memorize the Qur'an in early childhood, (3) Describe the supporting factors and (4) describe the factors inhibitors of memorizing the Qur'an in early childhood in PAUD Bait Qurany Saleh Rahmany. Research using qualitative descriptive methods. Data collection techniques used in this study were: interviews, observation and documentation. Data analysis in this study uses the interaction model of Miles and Huberman, with steps: data reduction, data presentation, conclusion drawing or verification. The results showed that: (1) the implementation of learning to memorize the Qur'an in early childhood is done by using the talqin method, memorization techniques with Jarimatika formula, with visual, audio and kinesthetic patterns, (2) the ability to memorize the Qur'an 'in children, namely the ability of natural talent that is trained repeatedly and optimally until it becomes an achievement, (3) supporting factors in memorizing the Qur'an, namely parent support, interests and talents, and adequate school facilities, (4) factors inhibitors in memorization are the internal factors of the child and the external factors of the child. The results of the research are recommended to be applied in all Paud based on Qur'an tahfiz by collaborating on the national curriculum and school-specific curriculum.
\end{abstract}

Keywords: Ability; memorize; Al-Qur'an.

\section{Introduction}

Memorization of the Qur'an is one form of interaction between Muslims that has been passed down for generations since the Qur'an was first revealed to the Prophet Muhammad. One process of maintaining the Qur'an is to memorize it for every generation of Muslims throughout the world. Teaching memorization of the Qur'an to early childhood, teachers are required to have the right method to teach according to the abilities of children. The development of a child's memory will be permanent when the child is golden age (golden age) and will reach the best intensity when the child is 8 to 12 years old. Memorization is an active effort in order to enter information into the brain. The ability to memorize is also interpreted as the ability to move the reading material to memorize is an active effort to be able to enter information into the brain or object into memory (encoding), store in memory (storage) and re-disclosure of the subject in memory (retrieval).

Memorizing the Qur'an in early childhood is done by playing the Qur'an reading by the teacher and imitating the child repeatedly until the child memorizes the verses that have been played. As a learning facility and infrastructure, schools have facilitated memorization of the Qur'an starting with short letters on chapter 30 of the Qur'an. The use of appropriate methods and strategies given to children will be able to support their memorization to be able to develop children's cognitive, language, spiritual intelligence and sharpen other complex intelligence in early childhood. Ability to memorize in early childhood can be influenced by 
several factors, including internal and external factors. Early childhood tends to be faster in memorizing, but not all children are able to memorize it well, the contributing factors include internal and external factors that occur in children.

\section{Review of Literature}

Early childhood development and growth during the golden age (golden age) will experience development and growth at a drastic rate and include thinking development, motor development, emotional development, social development, and physical development. According to Piaget (2009: 309), each child develops the ability to think according to its regular stages. at one stage of development a certain scheme or structure will emerge, whose success at each stage is very dependent on the previous stage. Ability is the capacity of an individual to perform various tasks in a job. Woodworth and Moga is in Suryabrata (1984: 169) define abilities (abilities) in three meanings, namely: a) achievement, which means the actual ability, which can be measured directly with certain tools or tests. b) capacity, which is a potential ability, which can be measured indirectly through measurement of individual skills, where these skills develop with a combination of basic training and intensive experience. c) aptitude, which is a quality that can only be revealed or measured by special tests that are deliberately made for it.

(Robbins, 2008: 66). Memorization is trying to absorb into the mind to always remember. Whereas the Qur'an in terminology according to Abu Syahbah is the Book of Allah SWT revealed, both lafazh and its meaning to the Prophet Muhammad which is narrated mutawwir namely with full certainty and confidence in its conformity with what was revealed to the Prophet Muhammad, written at the beginning of the Manuscripts from the letter Al-Fatihah to the end of the An-Nas letter, narrated is worth a miracle, read it is worth of worship and there is no doubt in it. From the above explanation it can be concluded that the definition of the ability to memorize the Qur'an means the ability to preserve or preserve the Qur'an as a revelation of God through the process of absorbing the verses of the Qur'an in accordance with the rules of reading the Qur'an ' in mind so that it can remember and recite it back without seeing the text or text.

\section{Research Method}

The research method used in this research is descriptive qualitative research. The theoretical ladder is used as a guide so that the focus of research is in accordance with the facts in the field besides the theoretical foundation is also useful to provide a general description of the research, according to the foundation of research results in the skin research of researchers, utilizing the existing theories as explanatory material, and ending with a conclusion. Subjects in this study were students of class B 8 whose samples were 2 (two) people who were quick to memorize (had been champions) and who were slow at memorizing and learning at PAUD Bait Qurany Saleh Rahmany in Banda Aceh. The data collection techniques used in this study were observation, interviews, and documentation. Analysis of data in research Data Reduction (data condensation), Data Presentation (data display), and Withdrawal Conclusions or Verification (conclusion drawing / verifcation). 


\section{Result and Discussion}

From the results of the analysis of the research above, in the process of implementing learning to memorize the Qur'an in PAUD Bait Qurany Saleh Rahmany, the teacher uses the Talqin (talaqqi) method to teach memorization to children, learning activities using classical learning models, in the implementation of learning memorization of the Qur'an The teacher uses quantum learning methods, the teacher guides, trains, optimally so that the child easily understands and follows what is directed by the teacher. Learning materials to memorize the Al-Qur'an at PAUD Bait Qurany Saleh Rahmany uses the Bait Qurany curriculum and the National curriculum which are combined so that the learning process is expected to be maximized.

In the process of implementing learning activities to memorize the Al-Qur'an in early childhood in PAUD Bait Qurany Saleh Rahmany, learning to memorize the Qur'an uses techniques with arithmetic or Jarimatika formulas, with visual, audio, and kinesthetic patterns. Learning activities to memorize the Al-Qur'an at PAUD Bait Qurany Saleh Rahmany using indoor and outdoor learning media. In learning activities to memorize the Qur'an with a quantum of Islamic excellence that is expected to make children able to love the Qur'an as a form of love for Allah and His Messenger.

From the results of the analysis of the above research, found that the ability to memorize the Koran in early childhood in PAUD Bait Qurany Saleh Rahmany is an ability that is a talent that already exists in children, scientific abilities that are owned by children with the process of memorizing are trained continuously so that children become memorized. The development of memorization in children is passed in stages according to the abilities possessed by the child. The achievement of memorizing the Qur'an in children is inseparable from the talents of the child, the interest in memorizing the Qur'an, the training that is done, the motivation and support from all parties.

The results of research analysis in the cognitive domain of children, is a very sensitive age in paud children. Children's cognitive abilities refer to how children process information conveyed by the teacher, children's intelligence, children's reasoning in expression, children's language development in saying and receiving language, and children's memory as storage. Increased ability to memorize the Qur'an in children is caused by the correct memorization method, memorization techniques that are easy for children to understand, and the stages achieved by repeating memorized items.

The results of research analysis in the spiritual realm of children, learning to memorize the Qur'an in the PAUD Bait Qurany Saleh Rahmany is carried out with a quantum personality for the formation of Islamic character of children, noble, religious education taught from an early age at school or in the family will be embedded and developed in yourself child. By learning to memorize the Al-Qur'an which is the Muslim holy book, children from childhood have been taught to know His Lord.

Many Factors That Support the Achievement of Memorizing the Qur'an in Children, in general there are internal factors which include talent, interest, intelligence (IQ). Talent which is an innate ability of a child brought from birth, interest is a permanent tendency to pay attention and remember activities that have been carried out by children, while intelligence (IQ) is the intelligence of a person using the mind, quickly or not remembering and solving a problem. 
Encouragement of learning and memorization also affects the external factors of the child, namely the influence of the family in the form of how parents educated, relationships between family members, motivation from the family, the atmosphere in the home and the economic situation of the child's family. While other supporting factors are the social environment of children in society, this effect occurs in general is a natural development that is the influence of children's learning places, such as schools, children's learning facilities, which affect the positive values of children in learning. The use of appropriate learning methods and in accordance with learning styles in early childhood will be able to facilitate the development of various potential abilities possessed in children optimally. A very important factor in a learning activity is inseparable from the use of good techniques and methods. Learning applied to early childhood needs to be adapted to the characteristics and learning styles of the child. In essence, children learn while playing and play while learning.

In the process of learning to memorize the Al-Qur'an at an early age children can also experience delay, this can occur because of the influence of factors that are usually not desired by children. One of the reasons that children forget about lessons is because the teacher has not found a child's learning style or learning strategy that is not right, the situation of children who are unhappy, situations where learning is not suitable, monotonous learning, boring delivery techniques, lack of motivation from the teacher or from family, and so on.

Factors that inhibit learning and the ability to memorize the Al-Qur'an PAUD Bait Qurany Saleh Rahmany in general the main factors that influence the slow memorization of the Koran in children are on internal factors and external factors, both of these factors that have a big influence on the ability to quickly or slowly children in memorizing the Qur'an. Barriers that occur cannot be separated from the lack of motivation to memorize children, lack of parental attention, low intelligence (IQ) of children, hearing loss, learning disorders, which makes children not focus on learning to memorize the Qur'an at school provided by the teacher.

In addition to applying learning methods to memorize the Qur'an that is appropriate to the age of the child, educators and parents must be aware of various inhibiting factors in memorizing the Qur'an on children which can occur anywhere and at any time. Educators and parents play a big role in teaching memorization of the Qur'an to children, the ability to memorize depends on the conditions faced by children. There is no theory that states the delay in memorizing the Qur'an in one child and other children in the same situation and conditions occur, because the factors that occur in the child's inhibition and influence from outside the child.

\section{Conclusion}

Conclusions based on the results of research on the Analysis of the Development of the Ability to Memorize the Qur'an in Early Childhood in PAUD Bait Qurany Saleh Rahmany of Banda Aceh, the systematic presentation is carried out by taking into account the formulation of the problem and research objectives that have been formulated and can be summarized as follows:

1. Learning to memorize the Al-Qur'an in early childhood which is applied in Bait Qurany Saleh Rahmany Kindergarten is to use the methodology conducted by the teacher to the child by reading the verses that will be memorized slowly by beheading and the child follows the reading, and so on. Until the child is able to 
Budapest International Research and Critics in Linguistics and Education (BirLE) Journal

Volume 2, No 4, November 2019, Page: 185-190

e-ISSN: 2655-1470 (Online), p-ISSN: 2655-2647 (Print)

www.bircu-journal.com/index.php/birle

emails: birle.journal@gmail.com

birle.journal.ga@gmail.com

memorize the letters in the Qur'an. The process of learning activities using the quantum method of Islamic personality with teaching techniques using the fingerprinting formula with visual, audio and kinesthetic patterns can develop motor skills, cognitive, language, and emotional and emotional intelligence and spiritual intelligence of children. With the Jarimatika formula used in learning to memorize the Qur'an in early childhood, the process of memorizing learning will train the right brain while counting can train the left brain.

2. The ability to memorize the Al-Qur'an in early childhood is the ability of children's talents, namely the ability of being inspired by the child with the process of memorization is trained continuously so that children become memorized. The development of memorization in children is passed in stages according to the abilities possessed by children. The achievement of memorizing the Qur'an in children is inseparable from the talents of the child, the interest in memorizing the Qur'an, the training that is done, the motivation and support from all parties.

3. Many factors that support the achievement of memorization of the Qur'an in early childhood in PAUD Bait Qurany Saleh Rahmany, there are internal factors in the child's self which include talent, interest, intelligence (IQ) and external factors that have an important influence in the form of motivation from family, school as a place of learning and social environment of children in the community.

4. Internal and external factors influence the inhibition of learning to memorize the Qur'an in early childhood in PAUD Bait Qurany Saleh Rahmany, which can occur usually undesirable factors for children. The reason is the condition of children who are un happy, the teacher has not found a child's learning style, lack of motivation from the teacher or from the family.

\section{References}

Anita, Y, (2011) Model Pendidikan Anak Usia Dini, Rawamangun Jakarta : Kencana Prenada Media Group.

Ahmad, S. (2011) Perkembangan Anak Usia Dini, Jakarta: Kencana Prenada Media Group. Abu Ahmadi and Munawar, S. (2005) Psikologi Perkembangan, Jakarta: PT. Rineka Cipta.

Anita, Y. (2011) Penilaian Perkembangan Belajar Anak Taman Kanak-Kanak, Rawamangun Jakarta: Kencana Prenada Media Group.

Arikunto, Suharsimi. (2010) Prosedur Penelitian Suatu Pendekatan Praktik. Yokyakarta: Rineke Cipta.

Ahsin W. (2000) Bimbingan Praktis Menghafal Al-Qur'an, Jakarta: Bumi Aksara.

Ahmad Hasan, (2008), Menghafal Al-Qur'an Itu Mudah. Jakarta: Pustaka At-Tazkia.

Armstrong, Thomas (1996) Multiple Intelegences In The Classroom. Virginia: Association For Supervision And Curriculum Development.

Abu Ahmadi and Widodo Supriyono, (1991) Psikologi Belajar, Jakarta : Rineka Cipta. Anas Sudjiono, (2005), Pengantar Evaluasi Pendidikan, Jakarta : PT Raja Grafindo Persada.

B.R.Hergenhanhn \& Matthen H.Olson. (Edisi Ketujuh). (2008) Theories of Learning. Rawamangun Jakarta: Kencana Prenada Media Group.

Bobby Deporter, et al. (2007) Quantum Learning. Bandung: Mizan Pustaka.

Chatrine Syarif, (2010), Menjadi Pintar Dengan Otak Tengah, Yokyakarta : PT Buku Kuta. 
Budapest International Research and Critics in Linguistics and Education (BirLE) Journal Volume 2, No 4, November 2019, Page: 185-190 e-ISSN: 2655-1470 (Online), p-ISSN: 2655-2647 (Print) www.bircu-journal.com/index.php/birle emails: birle.journal@gmail.com birle.journal.qa@gmail.com

Deporter, Bobbi Dan Mike Hernachi, Terj Alawiyah Abdurrahman, (2004), Quantum Learning : Membiasakan Belajar Nyaman Dan Menyenangkan, Bandung : Kaifa.

Deporter, Bobbi et al, (2000), Quantum Teaching : Mempraktekkan Quantum Learning Di Ruang Kelas, Bandung : Kaifa.

Faturrohman Pupuh \& M, Sobry Sutikno. (2017) Strategi Belajar Dan Mengajar, Strategi Mewujudkan Pembelajaran Bermakna Melalui Pemahaman Konsep Umum Dan Islam, Bandung : Refika Aditama.

Harun Rasyid, et al. (2009). Asesmen Perkembangan Anak Usia Dini. Yogyakarta: Multi Pressindo.

Isjoni. (2017) Model Pembelajaran Anak Usia Dini. Bandung : Alfabeta.

John W. Santrock.(edisi kedua : terjemahan), (2004) Psikologi Pendidikan, Rawamangun Jakarta : Kencana Prenada Media Group.

Janice J. Beaty. (Edisi Tujuh) (2013) Obserkgsi Perkembangan Anak Usia Dini. Terjemahan (Observing Devlopment Of The Young Child) Pearsoneducation, Inc. Penerjemah Arif Rakhman. Jakarta. Hal 268-372 : Kencana Group.

Jalaluddin, (2000) Psikologi Agama, Jakarta: Raja Grafindo Pesada.

Jalaluddin,R, (2014). SQ For Kids : Mengembangkan Kecerdasan Spiritual Anak Usia Dini Implikasi Bimbingannya, ejournal.radenitan.ac.id/dex.php/konseli.

James Deese Dan Stewart H Hulse, (1967) The Psikologi Of Learning. Usa : Mcgraw-Hill.

Muhammad Nur Abdul Hafizh Suwais. (2010). Prophetic Parentingcara Nabi Saw mendidik anak. Penerjemah: Farid Abdul Aziz Qurusy. Yogyakarta: Pro-U Media.

Masganti. (2011) Psikologi Agama, Medan : Perdana Publishing.

Mahmud Yunus (1990) Kamus Bahasa Arab. Jakarta : Hardika Agung.

Meleong. (2007). Metodelogi Penelitian Kualitatif. Bandung: Remaja Rosdakarya.

M.Ngalimpurwanto, (1992), Psikologi Pendidikan, Bandung; Remaja Rosdakarya.

Robins, Stephen P, Judge Timonthy A (2008) Terj Edisi 1, Prilaku Organisasi Buku 1, Jakarta :Salemba Empat.

Robinson Anwar, (2010), Ulum Al-Qur'an, Bandung : Pustaka Setia.

Salafuddin As. (2018) Ngaji Metal( Metode Talkim). Jakarta Selatan : Wali Pustaka.

Sumadi Suryabrata, (1984), Psikologi Pendidikan, Jakarta : Grafindo Persada.

Siswanto, W. (cet 2) (2010). Membentuk Kecerdasan Spiritual Anak, Jakarta : Amza.

Sugiyono. (2013).MetodePenelitian Pendidikan: Pendekatan Kuantitatif, Kualitatif, Dan $R \& D$. Bandung: Alfabeta.

Sa'dullah, (2008), Cara Cepat Menghafal Al-Qur'an, Jakarta : Gema Insani.

Suryani Lilis, et al, (2008), Metode Pengembangan Perilaku Dan Kemampuan Dasar Anak Usia Dini. Jakarta : Universitas Terbuka.

Suroso, Smart Brain, (2004), Metode Menghafal Cepat Dan Meningkatkan Ketajaman Memori, Yokyakarta : SIC.

Stephen P. Robin Dan Timonthy A. Judge, Terj, Diana Angelica, Dkk (2009), Prilaku Organisasi, Jakarta : Salemban Empat.

Slameto, (1995) Belajar Dan Faktor-Faktor Yang Mempengaruhinya, Jakarta: Rineka Cipta.

Tim Penyusun Kamus Besar Bahasa Indonesia, (2005), Kamus Besar Bahasa Indonesia, Jakarta: Balai Pustaka. 2005.

Yusuf Mansur \& Luthfi Yansyah. (2017) Dahsyatnya Membaca dan Menghafal Al-Qur'an. Rawamangun Jakarta: Zikrul Hakim.

Zuhairini, et al. (1993). Metodelogi Pendidikan Agama, Solo : Ramadhani.

Zaki Zamani \& M. Syukron Maksum. (2014) Metode Cepat Menghafal Al-Qur'an, Yogyakarta : Al Barokah. 